\title{
Influence of organic and inorganic sources of nutrients on the nutrient uptake and yield of groundnut (Arachis hypogaea L.) in two texturally different soils
}

\section{P. KAMALAKANNAN AND M. RAVICHANDRAN}

Received : 20.09.2014; Revised : 28.10.2014; Accepted : 15.11 .2014

\section{MEMBERS OF RESEARCH FORUM: \\ Corresponding author : \\ P. KAMALAKANNAN, Department of \\ Soil Science and Agricultural Chemistry, Faculty of Agriculture, \\ Annamalai University, Annamalai \\ Nagar, CHIDAMBARAM (T.N.) INDIA \\ Email:kamal_soil@yahoo.co.in}

\section{Co-authors :}

M. RAVICHANDRAN, Department of Soil Science and Agricultural Chemistry, Faculty of Agriculture, Annamalai University, Annamalai Nagar, CHIDAMBARAM (T.N.) INDIA

\section{Summary}

Field experiments were carried out in a farmers field at Chinnathanakuppam and Ayeekuppam villages, Cuddalore district during December, 2008 and March, 2009 to evaluate suitable organic and inorganic sources of nutrients to groundnut crop. The experimental soil at Chinnathanakuppam village belongs to Vadalapakkam series (Typic rhodustalf) with sandy clay loam texture having $\mathrm{pH}-7.8$ and $\mathrm{EC}-0.36 \mathrm{dS} \mathrm{m}^{-1}$. The soil was low in organic carbon $\left(3.4 \mathrm{~g} \mathrm{~kg}^{-1}\right)$, medium in alkaline $\mathrm{KMnO}_{4}-\mathrm{N}\left(285 \mathrm{~kg} \mathrm{ha}^{-1}\right)$, low in Olsen-P $\left(11.0 \mathrm{~kg} \mathrm{ha}^{-1}\right)$ and medium in $\mathrm{NH}_{4} \mathrm{OAC}-\mathrm{K}\left(190 \mathrm{~kg} \mathrm{ha}^{-1}\right)$. The experimental soil at Ayeekuppam village belongs to Vadapudupet series (Typic haplustalf) with loamy sand in texture, having a pH-8.1 and EC-0.41 dSm${ }^{-1}$. The soil was low in OC $\left(2.8 \mathrm{~g} \mathrm{~kg}^{-1}\right)$, low in available $\mathrm{N}\left(230 \mathrm{~kg} \mathrm{ha}^{-1}\right)$ and $\mathrm{P}\left(9.0 \mathrm{~kg} \mathrm{ha}^{-1}\right)$ and medium in available $\mathrm{K}\left(160 \mathrm{~kg} \mathrm{ha}^{-1}\right)$. The experiment was conducted with 16 treatment combinations. The treatments consisted of different levels of NPK viz., 100 per cent, 75 per cent and 50 per cent RDF and different sources of nutrients viz., farm yard manure@12.5 tha-1 , fly ash@ $10 \mathrm{t} \mathrm{ha}^{-1}$ and humic acid @ $20 \mathrm{~kg} \mathrm{ha}^{-1}$ along with micronutrients boron@ 10 $\mathrm{kg} \mathrm{ha}^{-1}$ and zinc sulphate @ $25 \mathrm{~kg} \mathrm{ha}^{-1}$. The experiments was laid out in Randomized Block Design with three replications and tested with groundnut crop variety JL-11. The results indicated that application of 100 per cent $\mathrm{RDF}+\mathrm{FYM}+\mathrm{ZnSO}_{4}+$ boron $\left(\mathrm{T}_{8}\right)$ recorded the highest pod and haulm yields of 2853 and $4573 \mathrm{~kg}$ $\mathrm{ha}^{-1}$ in sandy clay loam soil and 2415 and $3578 \mathrm{~kg} \mathrm{ha}^{-1}$ in loamy sand soil, respectively. Among the sources tried, FYM was superior in the performance of yield. Similarly in major nutrients uptake, treatment $\mathrm{T}_{8}$ showed significant variation with remaining treatments.

Key words : Organics, Inorganics, Micronutrients, Groundnut crop, Texturally different soils, Yield

How to cite this article : Kamalakannan, P. and Ravichandran, M. (2014). Influence of organic and inorganic sources of nutrients on the nutrient uptake and yield of groundnut (Arachis hypogaea $\mathrm{L}$.) in two texturally different soils. Asian J. Soil Sci., 9(2): 271-275. 